\title{
A Case with Perirenal-Perihepatic-Bony Pelvic Hematoma That Presented with Syncope Following ESWL
}

Olgu Sunumu Case Report
Alındığı tarih: 06.02.2019 Kabul tarihi: 20.02.2019 Online Yayın tarihi: 28.03.2020

Mehmet Zeynel Keskin Tepecik Training and Research Hospital, Department of Urology, Izmir - Turkey zeynel_akd@hotmail.com ORCID: 0000-0002-9206-5586

Y.ö. İlbey 0000-0002-1483-9160 Tepecik Training and Research Hospital, Department of Urology, Izmir, Turkey

Cite as: Keskin MZ, Ilbey Yo. A case with perirenal-perihepatic-bony pelvic hemato-
ma that presented with syncope following ESWL. Tepecik Eğit. ve Araşt. Hast. Dergisi. 2020;30(1):104-7.

\section{ESWL Sonrası Senkop ile Başvuran Perirenal-Perihepatik- Kemik Pelvis içi Hematom Vakası}

\author{
Mehmet Zeynel Keskin $\odot$, Yusuf Ozlem Ilbey $\odot$
}

\begin{abstract}
Following ESWL, symptomatic subcapsular/perirenal hematomas are detected by USG at a rate of $4 \%$ while symptomatic hematomas are encountered at rates of $<1.5 \%$. This rate is reported to reach up to $30 \%$ with Computed Tomography (CT) and Magnetic Resonance Imaging (MRI). By presenting our approach to a case diagnosed with perirenal hematoma following ESWL in this study, we aimed to remind that this condition, which is considered as a major complication in the literature, can result in hypotension that could sometimes threaten survival, and to stress the importance of CT in ensuring that the diagnosis is not overlooked.
\end{abstract}

Keywords: ESWL, subcapsuler, perirenal, hematoma

ÖZ

ESWL sonrası USG ile asemptomatik subkapsüler/perirenal hematom \%4 düzeylerinde görülürken, semptomatik hematom ise <\%1,5 oranında görülür. Bilgisayarlı Tomografi (BT) ve Manyetik Rezonans Görüntüleme (MRG) ile bu oranın \%30 düzeyine çıktığı belirtilmektedir. Bizde bu çalışmamızda, ESWL sonrası perirenal hematom saptanan olgumuza yaklaşımımızı sunarak, literatürde major komplikasyon olarak değerlendirilen bu durumun bazen yaşamı tehdit edebilme derecesine gelebilecek hipotansiyonlara neden olabileceğini hatırlatmak ve tanının atlanmaması için BT'nin önemini vurgulamak istedik.

Anahtar kelimeler: ESWL, subkapsüler, perirenal, hematom

\section{INTRODUCTION}

The introduction of Extracorporeal Shockwave Lithotripsy (ESWL) in the 1980s brought about very important developments regarding the management of renal and ureteral stones. Currently, ESWL is being used routinely, particularly in the treatment of stones localized in the renal pelvis, middle-upper calyx, and proximal ureter ${ }^{(1,2)}$. Although uncommon, ESWL is associated with certain complications despite its noninvasive nature. Most
ESWL complications are mild. ESWL complications may be evaluated under three categories; residual stone fragments, infection, and tissue effect ${ }^{(3)}$. Renal complications induced by the tissue effect may manifest as hematuria and hematoma in the early period, as well as kidney failure and renovascular hypertension in the long-term ${ }^{(3,4)}$. Symptomatic subcapsular/perirenal hematomas following ESWL are encountered in ultrasonography (USG) at a rate of $4 \%$ while symptomatic hematomas are encountered at rates (c) Telif hakkı T.C. Sağık Bakanlığı İzmir Tepecik Eğit. ve Araşt. Hastanesi. Logos Tıp Yayıncılık tarafindan yayınlanmaktadır. Bu dergide yayınlanan bütün makaleler Creative Commons Atf-GayriTicari 4.0 Uluslararası Lisansı ile lisanslanmıștır.

(c) Copyright Association of Publication of the T.C. Ministry of Health Izmir Tepecik Education and Research Hospital.

(c) Copyright Association of Publication of the T.C. Mini

This journal published by Logos Medical Publishing.
Licenced by Creative Commons Attribution-NonCommercial 4.0 International (CC BY-NC 4.0) 
of $<1.5 \%$. According to the literature, this rate reaches up to $30 \%$ with the use of Computed Tomography (CT) and Magnetic Resonance Imaging (MRI) ${ }^{(5,6)}$. Thus, it can be stated that USG remains inadequate in detecting hematoma complications after ESWL. By presenting our approach to a case diagnosed with perirenal hematoma following ESWL in this study, we aimed to remind that this condition, which is considered a major complication in the literature, can result in hypotension that could sometimes threaten survival.

\section{CASE PRESENTATION}

A 67-year-old male patient, who did not use anticoagulants, underwent 2 sessions of ESWL treatment for a $1.2-\mathrm{cm}$ stone localized in the left renal pelvis and an 8-cm simple cyst in the lower pole of the left kidney (Figure 1A-B). The patient, who had been discharged on the same day, was brought to the emergency service by his family due to a syncope experienced in the evening at his home. His $\mathrm{Hb}$ level at initial admission was $13 \mathrm{gr} / \mathrm{dL}$ and his blood pres-

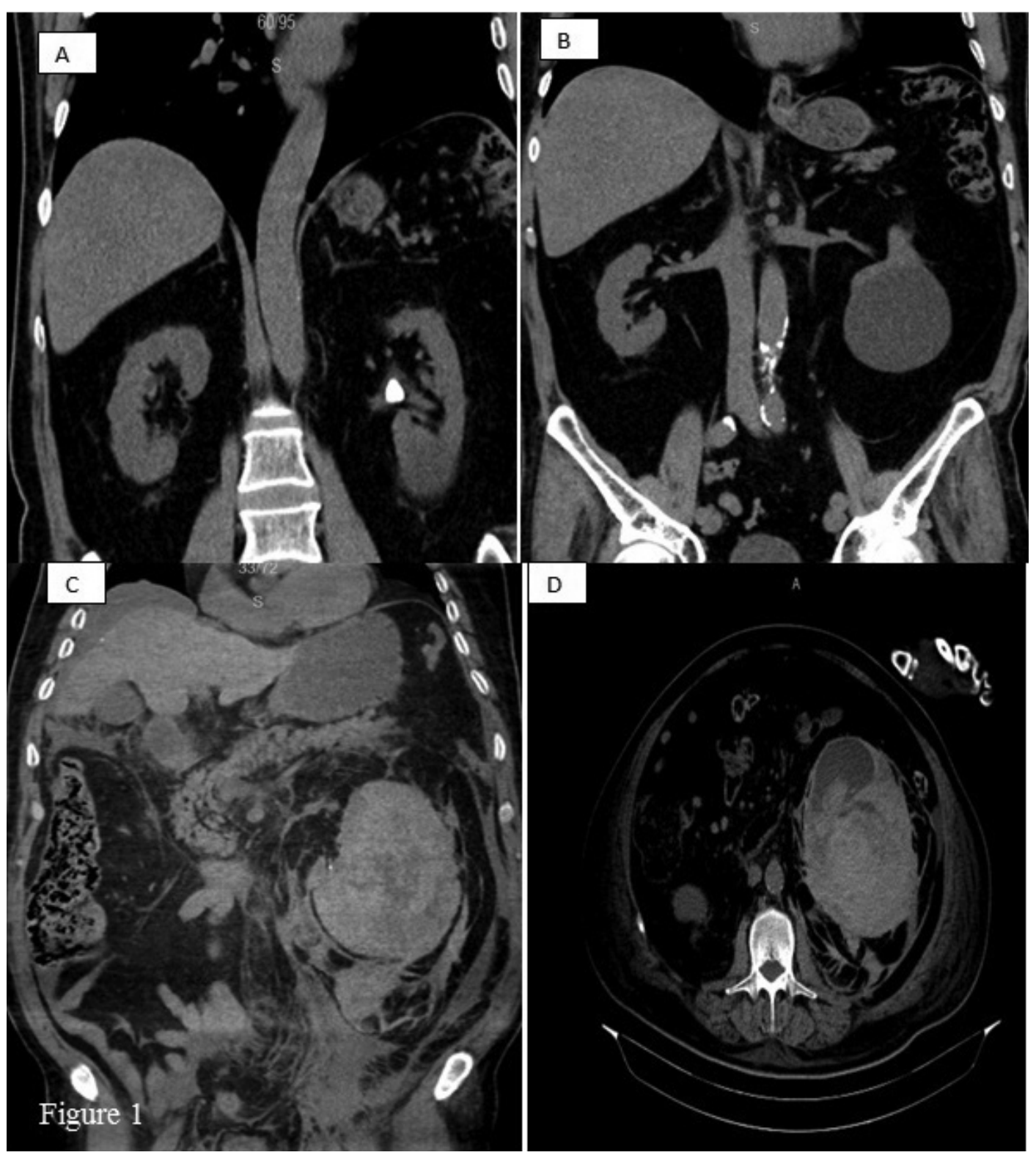

Figure 1. 
sure (BP) was $60 / 30 \mathrm{mmHg}$, therefore, an intravenous fluid replacement was performed. Results from his CT scan taken subsequently demonstrated a nearly $10-\mathrm{cm}$ hematoma with a dense content, which was localized in the left perirenal space and reached a more significant size in the inferior region. Moreover, there was minimal amount of free hyperdense fluid in the perihepatic space and in the bony pelvis region which suggested active bleeding (Figure $1 \mathrm{C}-\mathrm{D})$. The case was hospitalized in our urology service. $\mathrm{Hb}$ level measured one hour after fthe initial $\mathrm{Hb}$ result was obtained was $10.9 \mathrm{gr} / \mathrm{dL}$. In total, 5 units of erythrocyte suspension (ERT) were transfused, and the patient who manifested hypotension and syncopal episodes while being monitored, was transferred to the intensive care unit and intubated by the reanimation team. During his follow-up at the intensive care unit, his $\mathrm{Hb}$ regressed to levels as low as 6.5 $\mathrm{gr} / \mathrm{dL}$. Transfusion of blood components was therefore sustained based on the suggestion of the hematology clinic. A consultation was made with the interventional radiology clinic for the case, whose bleeding appeared to persist fin the meanwhile or embolization, but embolization was not performed as his angiography could not demonstrate bleeding foci. The patient was intubated for almost one week, and received 12 units of ERT and 8 units of fresh frozen plasma (FFP) in all His general condition then ameliorated, with $\mathrm{Hb}$ levels reaching $11.2 \mathrm{gr} / \mathrm{dL}$ and BP levels reaching 100/65 mmHg. The case was thus discharged with suggestions on the $13^{\text {th }}$ day following his presentation to the emergency service.

\section{DISCUSSION}

Although complications such as subcapsular and perirenal hematoma are conditions encountered more commonly due to trauma and tumoral pathologies, they may rarely develop iatrogenically following urological surgeries. While they are particularly uncommon after endoscopic procedures such as ureteroscopy (URS) with rates $<0.1 \%$, they are relatively more common after ESWL (4\%) ${ }^{(7)}$. Among mini- mally invasive urological surgeries, subcapsular/perirenal hematoma primarily connotates ESWL ${ }^{(8)}$. A review of the literature shows that the most common complications following ESWL are serious colicky pain induced by stone fragments (40\%) and macroscopic hematuria (32\%) ${ }^{(5,9)}$. Associated macroscopic hematuria usually does not require blood transfusion and the patients are followed-up conservatively. Hematoma, on the other hand, is a much rarer complication, and while conservative follow-up is usually sufficient, embolization and surgery may be needed in rare cases. In the conservative approach, the condition may take between 6 weeks- 6 months to resolve ${ }^{(9,10)}$. While complications of perihepatic, periscrotalhematoma are rarely reported after ESWL of kidney stones, most commonly cases of perirenal hematoma( have been indicated (11,12). Dhar et al. (13) reported rates of asymptomatic, and symptomatic subcapsular/perirenal hematoma following ESWL as $4.1 \%$ and $4 \%$, respectively, whereas these corresponding rates were rreported as $4.1 \%$ and $0.7 \%$ in another study ${ }^{(5)}$. Although rarely, complications as perirenal hematomas leading to death have been reported, and the diagnosis can often be overlooked or delayed when USG is preferred instead of CT $(14,15)$. The chief complaints of post-ESWL hematoma patients are colicky pain and hematuria. If a patient who presents with these complaints also has a history of ESWL, more attention must be paid to the appearance of these symptoms, CT should be preferred as the imaging method, and the patient must be monitored ${ }^{(9)}$. According to studies in the literature, risk factors for post-ESWL subcapsular/ perirenal hematoma include HT, coagulopathies, thrombocytopenia, diabetes mellitus (DM), coronary artery disease, atherosclerosis, obesity, advanced age, presence of calyceal stones, larger stone size, higher number and voltages of shockwaves applied $(10,14,16)$. Lee et al. ${ }^{(14)}$ investigated the risk factors associated with post-ESWL hematoma by comparing the control group without post-ESWL hematoma with post-ESWL hematoma group with regard to age, gender, number of shockwaves, body mass index (BMI), 
stone size, and $\mathrm{HT}$, and they found that the last three parameters were higher or more common in the hematoma group. Based on the above-mentioned study, a complication of hematoma is more common in cases with stone sizes larger than $1 \mathrm{~cm}$ and BMI values higher than $25 \mathrm{~kg} / \mathrm{m}^{2}$. In our case, stone size prior to ESWL was measured as $1.2 \mathrm{~cm}$ and $\mathrm{BMI}$ as $28.8 \mathrm{~kg} / \mathrm{m}^{2}$ corroborating the results of Lee et al. A study by El-Nahas et al. ${ }^{(17)}$ evaluated the risk factors for post-ESWL complications that require hospitalization and determined that hospitalization was positively correlated with age, stone size, presence of $\mathrm{HT}$, a high American Society of Anesthesiologists (ASA) score, presence of a solitary kidney, and accompanying hydronephrosis. The mentioned study did not evaluate BMI as a risk factor. On the other hand, Dhar et al. ${ }^{(13)}$ diverged from the literature by reporting that HT was not a risk factor and considered advanced age as a risk factor. In our case, the patient was 67 years old, HT was present in his preoperative history, and his ASA score was 2. Our case partially confirms the study by El-Nahas et al. However our case did not have hydronephrosis or a solitary kidney. Additionally, our case had an 8-cm simple cyst in the left kidney and we think that a renal cyst is also a risk factor for post-ESWL hematoma. In our case, perirenal hematoma also extended into the perihepatic space and the bony pelvis. While the literature contains rare cases of perirenal hematomas in relation to either the perihepatic space or the bony pelvis/scrotum, our case is the first where a perirenal hematoma is accompanied by a hematoma with both perihepatic and bony pelvic localization. In conclusion, one must be alert in cases of perirenal hematoma, which is a complication that may result in death, and particularly, patients who present with hematuria and pain after ESWL must not be sent home after an USG and pain management. These cases must absolutely be examined with $\mathrm{CT}$ and monitorization must be ensured when necessary.

Conflict of Interest: None. Informed Consent: None.

\section{REFERENCES}

1. Chaussy C, Schuller J, Schmiedt E, et al. Extracorporealshockwavelithotripsy (ESWL) for treatment of urolithiasis. Urology. 1984;23:59-66. [CrossRef]

2. Segura JW, Preminger GM, Assimos DG, et al. Ureteral Stones clinical guidelines panel summary report on the management of ureteral calculi. J Urol. 1997;158:1915-21. [CrossRef]

3. Skolarikos A, Alivizatos G, de la Rosette J. Extracorporeal shockwave lithotripsy 25 years later: complications and their prevention. Eur Urol. 2006;50:981-90. [CrossRef]

4. Karlsen SJ, Smevik B, Hovig T. Acute morphological changes in canine kidneys after exposure to extracorporeal shockwaves: A light and electronmicroscopic study. Urol Res. 1991;19:105-15. [CrossRef]

5. Salem S, Mehrsai A, Zartab H, et al. Complications and outcomes following extracorporeal shockwave lithotripsy: a prospective study of 3,241 patients. Urological Research. 2010;38(2):135-42. [CrossRef]

6. Dhar NB, Thornton J, Karafa MT, et al. A multivariate analysis of risk factors associated with subcapsular hematoma formation following electromagnetic shockwave lithotripsy. J Urol. 2004;172:2271-4. [CrossRef]

7. Bansal U, Sawant A, Dhabalia J. Subcapsular renal hematomaafter ureterorenoscopy: an unknown complication of a known procedure. Urol Ann. 2010;2:119-21. [CrossRef]

8. Navarro HP, López PC, Ruiz JM. Renal hematoma after extracorporeal shock-wavelithotripsy (ESWL). Actas Urol Esp. 2009;33:296-303.

9. Silberstein J, Lakin CM, Kellogg Parsons J. Shockwavelithotripsy and renal hemorrhage. Rev Urol. 2008;10:236-41.

10. Tailly GG. Management of acute post ESWL complications. Ceská Urol. 2000;4:5-8.

11. Kim TB, Park HK, Lee KY, et al. Life-threatening complication after extra corporeal shock wave lithotripsy for a renal stone: a hepatic subcapsular hematoma. Korean Journal of Urology. 2010;51(3):212-5. [CrossRef]

12. Ou YL, Liu CY, Wu ST, et al. Perirenal Hematoma Extending to the Ipsilateral Scrotum Region after Shock Wave Lithotripsy Treatment. J Med Sci. 2018;XX(XX):1-3.

13. Dhar NB, Thornton J, Karafa MT, et al. A multivariateanalysis of risk factors associated with subcapsular hematoma formation following electromagnetic shockwave lithotripsy. J Urol. 2004;172:2271-4. [CrossRef]

14. Lee HY, Yang YH, Shen JT, et al. Risk factors survey for extra corporeal shock wave lithotripsy-induced renal hematoma. Journal of Endourology. 2013;27(6).763-7. [CrossRef]

15. Uemura K, Takahashi S, Shintani-Ishida K, et al. A death due to perirenal hematoma complicating extracorporeal shockwave lithotripsy. Journal of Forensicsciences. 2008;53(2):46971. [CrossRef]

16. Willis LR, Evan AP, Connors BA, et al. Prevention of lithotripsyinduced renal injury by pretreating kidneys with low-energy shockwaves. J Am Soc Nephrol. 2006;17:663-73. [CrossRef]

17. EL-Nahas AR, Taha DE, Elsaadany MM, et al. Hospital admission for treatment of complications after extracorporeal shockwave lithotripsy for renal stones: a study of risk factors. Urolithiasis. 2018;46(3):291-6. [CrossRef] 